\title{
Short Communication: Behavioral study on Anguilla bicolor using a modified trap design at laboratory scale
}

\author{
ARISTI DIAN PURNAMA FITRI ${ }^{1, \bullet}$, HERRY BOESONO ${ }^{1}$, FAIK KUROHMAN ${ }^{1}$, BOGI BUDI JAYANTO ${ }^{1}$, \\ DESCA ESTIYANI DEWI ${ }^{2}$, AGUS SABDONO ${ }^{3}$ \\ ${ }^{1}$ Department of Fishing Capture, Faculty of Fisheries and Marine Science, Universitas Diponegoro. Jl. Prof. Soedarto, SH, Tembalang, Semarang 50275, \\ Central Java, Indonesia. Tel. / Fax.: +62-24-7474698, "email: aristidian@ fisika.undip.ac.id \\ ${ }^{2}$ Coastal Resources Management Postgraduate Program, Faculty of Fisheries and Marine Science, Universitas Diponegoro. Jl. Prof. Soedarto, SH, \\ Tembalang, Semarang 50275, Central Java, Indonesia \\ ${ }^{3}$ Department of Marine Science, Faculty of Fisheries and Marine Science, Universitas Diponegoro. Jl. Prof. Soedarto, SH, Tembalang, Semarang 50275, \\ Central Java, Indonesia
}

Manuscript received: 29 May 2019. Revision accepted: 14 July 2019.

\begin{abstract}
Fitri ADP, Boesono H, Kurohman F, Jayanto BB, Dewi DE, Sabdono A. 2019. Short Communication: Behavioral study on Anguilla bicolor using a modified trap design at laboratory scale. Biodiversitas 20: 2159-2165. The information on the behavioral juvenile eels Anguilla bicolor is urgently needed as basic design of selective and sustainable traps. The objectives of this study were to find out and analyze the behavioral pattern and characteristics of A. bicolor elvers in the modified and non-modified eel traps. The test organism, A. bicolor juvenile eels with $150-170 \mathrm{~mm}$ in length, were obtained from Segara Anakan waters, Cilcacap. The 2 trap designs, which were modifications of the $450 \mathrm{~mm}$ long PVC eel trap, with and without the addition of bait hole, were used in this study. All experiments were carried out in the laboratory of Fish Behavior, Diponegoro University, Semarang, Indonesia. The eel characters and response time were recorded using a handy camera that placed on top of the aquariums. The results indicated six types of A. bicolor behavior in response to the modification of eel traps. Moreover, the trap design with an additional hole on the wall, with or without bait, was proven to have no significant effect on the response time. While trap without column and bait possessed the fastest response time at which elver penetrated to the trap ( $p$-value $\leq 0.05$ ). Furthermore, these results indicated that $A$. bicolor elver gained entrance into the trap, in an attempt to take shelter.
\end{abstract}

Keywords: Anguilla bicolor, behavior, eel trap, shelter

\section{INTRODUCTION}

Anguilla sp. belongs to catadromous biota, which lives in estuarine ecosystems (Righton and Metcalfe 2011; Shrimpton 2013; Zydlewski and Wilkie 2013; Bultel et al. 2014; Miller and McCleave 2018). However, the types commonly found in Indonesia, include A. celebesensis (endemic eels in the islands of Borneo and Sulawesi), A. interioris, A. obscura (in the waters of Papua), A. marmorata, A. bicolor bicolor, and A. bicolor pacifica (in the waters of Java) (Putra 2015). Furthermore, A. bicolor is easily spotted in the waters of Pelabuhan Ratu, West Java and that of Segara Anakan in Cilacap district, Central Java (Nijman 2015; Haryono and Wahyudewantoro 2016). The development of this organism consists of six phases, including egg, larvae (leptocephalus), glass eel, elver, fingerling (yellow eel), and adult (silver eel) (Miller and McCleave 2018; Verhelst et al. 2018). Their living habitat includes in the continental and ocean waters. The newly hatched larvae drift with the ocean currents, grow into glass eels and elver in the continental waters. The growth of fingerling phase may happen in freshwaters, brackish (transitional), or marine, then in adult phase migrates to the sea to breed, spawn and dies after spawning (Righton and
Metcalfe 2011; Bultel et al. 2014; Miller and McCleave 2018). Anguilla sp. is a nocturnal creature, which feeds by utilizing its olfactory organ, just like any other nocturnal biota (Weltersbach et al. 2019; Fitri 2012).

The device trap that constructed from a 4-inch thick PVC with $450 \mathrm{~mm}$ in length is used to capture Anguilla sp. in the Segara Anakan waters, Central Java. The capture took place late in the afternoon, with a 12-hour immersion. This timing is selected to match the organism's hours of activity as nocturnal biota. The fish and shrimp baits are used to attract even more Anguilla sp. Furthermore, the holes are made at the top of the trap construction, in order to allow chemical attractants to spread faster outside of the trap. Hence, it is assumed that eels become more willing to enter the entrapment.

According to the past studies, tropical eel species $A$. bicolor have been found in the south coast of Java island (Setiawan et al. 2001; Honda et al. 2016; Taqwa et al. 2017). However, these studies have mainly focused on the population dynamics, nutritional feeds, habitat ecology of the anguillid eels (Sugeha and Genisa 2015; Lukas et al. 2017; Handajani et al. 2018). Little effort has been made to examine the fish behavior of the anguillid eels. Shiao et al. (2003) and Chen et al. (2018) reported migratory behaviors 
and habitat use in Taiwan. However, information concerning the behavior of A. bicolor elver, using modified traps has not been explored-hence the need for this investigation. This study was aimed at identifying and analyzing patterns and characteristics of A. bicolor for both modified and non-modified eel trap in the laboratory scale.

\section{MATERIALS AND METHODS}

This research was carried out in the laboratory of Fish Behavior, Department of Fishing Capture, Faculty of Fisheries and Marine Science, Diponegoro University, Indonesia. Furthermore, the objects were A. bicolor elvers, obtained from the waters of Segara Anakan in Cilacap, Central Java, Indonesia using eel traps.

The organism was of medium size, with a total length (TL) of 150-170 mm. The eel traps were made into two designs, each with a length of $450 \mathrm{~mm}$, a hole was put into one (modified), while the other had no holes (control). Furthermore, the opening at the top of the device allowed a faster dispersion of chemicals than the bait, in order to accelerate detection through its olfactory organ, to enhance the efficiency of the immersion time. The PVC pipe contained 64 holes on each, with a diameter of $0.50 \mathrm{~cm}$. The specification for each part of the set up is shown in Figures 1,2, 3, and 4, while that of the modified apparatus was illustrated in Figures 5 and 6.

The baits used as attractants were bits of Penaea sp., which were hanged in the body of the trap. Furthermore, they are one of the biota, A. bicolor feeds on in nature (Engman et al. 2017; Miller and McCleave 2018).

Observation for treatment was performed with the simulation of $A$. bicolor capture, using traps in the designated aquarium, including the application of the 450 $\mathrm{mm}$ long modified trap, which consists of two designs (with and without lattice). Furthermore, other procedures applied during the study involved the use and absence (control) of bait on each constructed device, intending to determine the response and behavior of A. bicolor from different dealings. During the capture operation, both traps were put in separate aquariums and observed for 60 minutes, in line with the rate of chemical dispersion from attractants or baits (Penaea sp.) to lure optimal catch (Fitri 2012; Fitri et al. 2017b). Moreover, these processes were carried out in the evening, in an attempt to match the nature of A. bicolor as nocturnal biota (Fitri et al. 2017a). Prior to the observation, the organism had to undergo pretreatment, where it was left without food for 24 hours, enabling them to respond better during the process. The surveillances were carried out to collect data of response time and behavior of $A$. bicolor as they approach and enter the traps. Furthermore, a timer, indicating how long it takes for A. bicolor to gain entrance into the device (in seconds) was used as an indicator. Data were collected during capture simulation by utilizing handy cameras, placed across the on top of the aquariums (Figures 7 and 8).

\section{RESULTS AND DISCUSSION}

Fish behavioral habits in response to their surrounding are either positively (taxis) and negative (phobias) (Fitri 2012; Gutowsky et al. 2017; Pouca and Brown 2017; Benitez et al. 2018; Suriyampola et al. 2018). This research revealed six patterns of behavior of A. bicolor elver against different trap designs, which include: (i). reaching straight into the trap, (ii). holding still and hiding beside the device, (iii). staying calm at the trap entrance facing outward, (iv). reaching for the inside of the trap and holding still within, (v). swimming toward the top of the trap near the hole of the bait, (vi). moving around the device. Hence, an illustration during treatment is shown in Figure 9.

The primary response of the organism during the immersion of a trap into the aquarium was an approach into the PVC eel trap. This behavioral response was due to the natural curiosity of biota (thigmotaxis nature) against any new object in their surroundings (Bolliet et al. 2007; Fitri et al. 2017a). In addition, this reaction was also due to the perception that the trap could function as a shelter. Hence, it is perceived as protection from another biota of the same or different species (von Brandt 2005). Furthermore, solitary biota tends to find their own space and attempt to hide in any shelter they discover. The response of approaching the trap and swimming to the hole indicated a process of chemical dispersion from the bait. This dispersion stimulated the nocturnal biota with olfactory organ (Hara 2011; Atta 2013; Fitri et al. 2017b). Atta (2013) and Engman et al. (2017) reported that the olfactory organ of A. bicolor is more dominant than that of visual counterpart.

The response of the organism to stay motionless under the trap was an attempt to hide. This behavior is a natural response regards that treatment may sign indication of threat. One of the natural traits of A. bicolor as a group of demersal fish is its tendency to hold still and hide in any spot regarded safe from certain predators. Eel's body shape permits the performance of undulation moves when they swim which enables them to stay calm and hide (Bergstad 2009; Miller and McCleave 2018).

\section{$89 \mathrm{~mm}$}

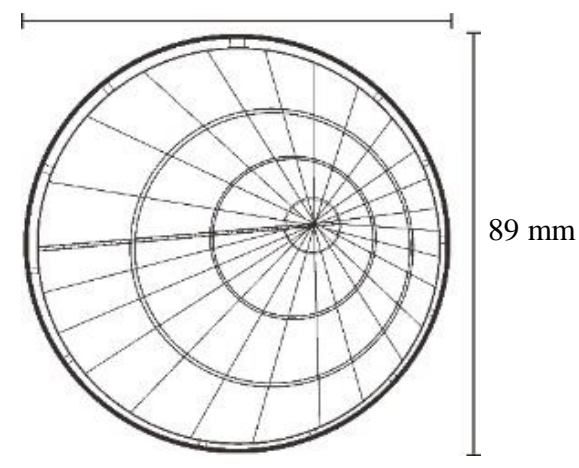

Figure 1. Design of eel trap opening (front view) 


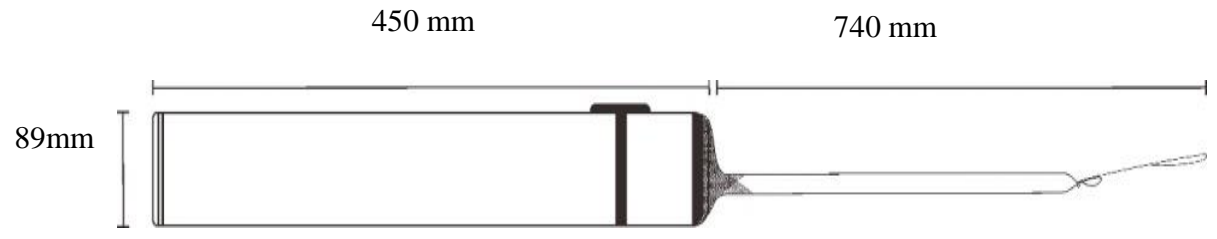

Figure 2. Eel trap design (side view)

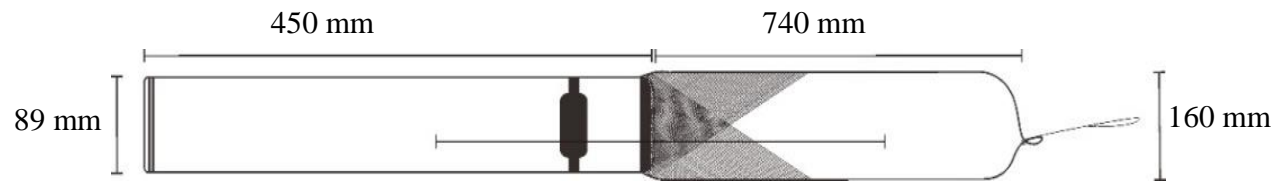

Figure 3. Eel trap design (top view)

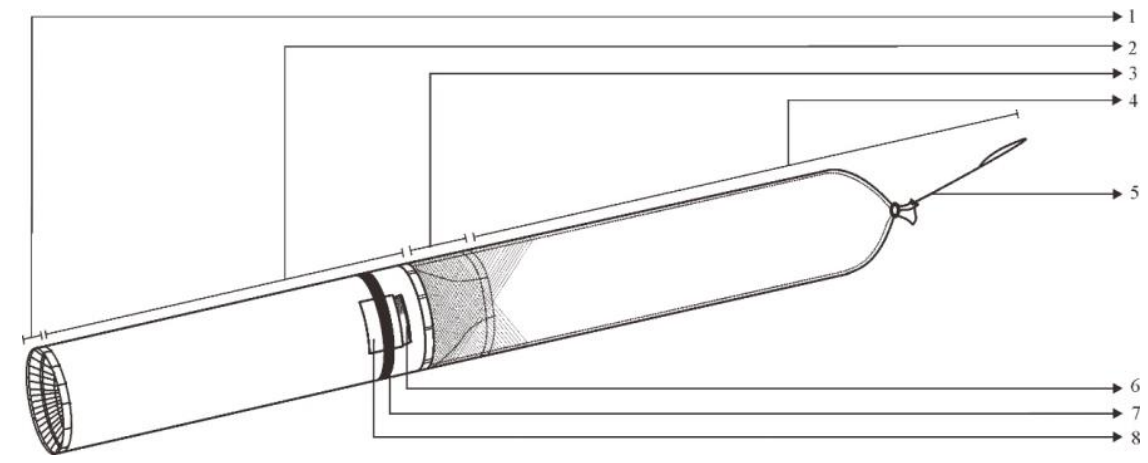

Note:
1. The main door of PVC traps
5. Anchor rope of PVC trap
2. Body of PVC trap
6. Bait box of trap
3. Doors of PVC trap
7. Rubber band for the bait of PVC trap
4. The casing of PVC traps
8. Baitholder of PVC trap

Figure 4. Eel trap specification

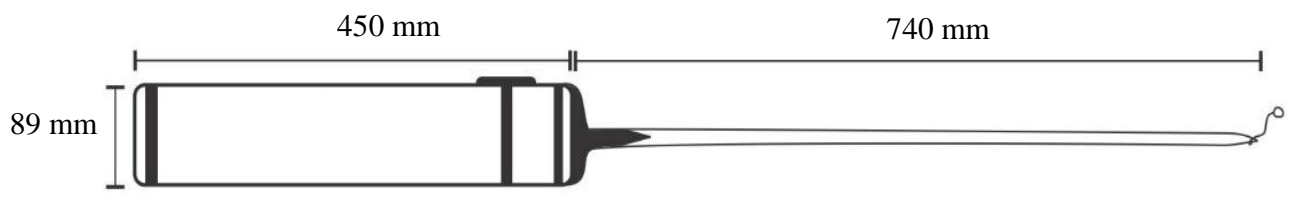

Figure 5. Eel trap construction without additional holes (control)

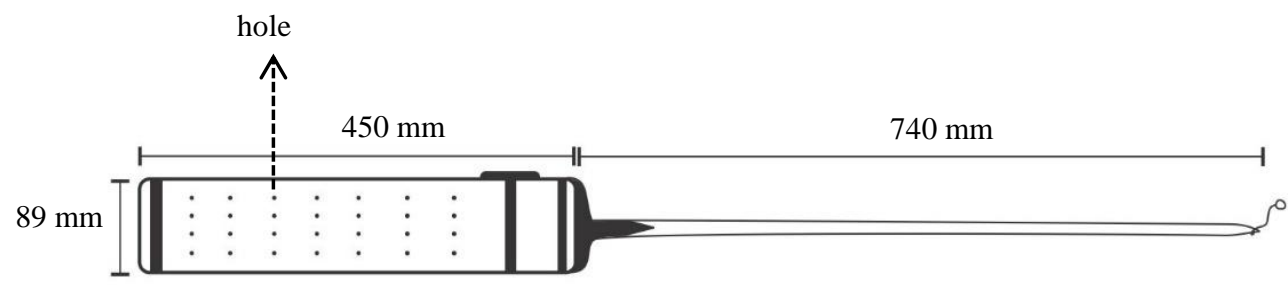

Figure 6. Eel trap construction with additional holes (modified) 


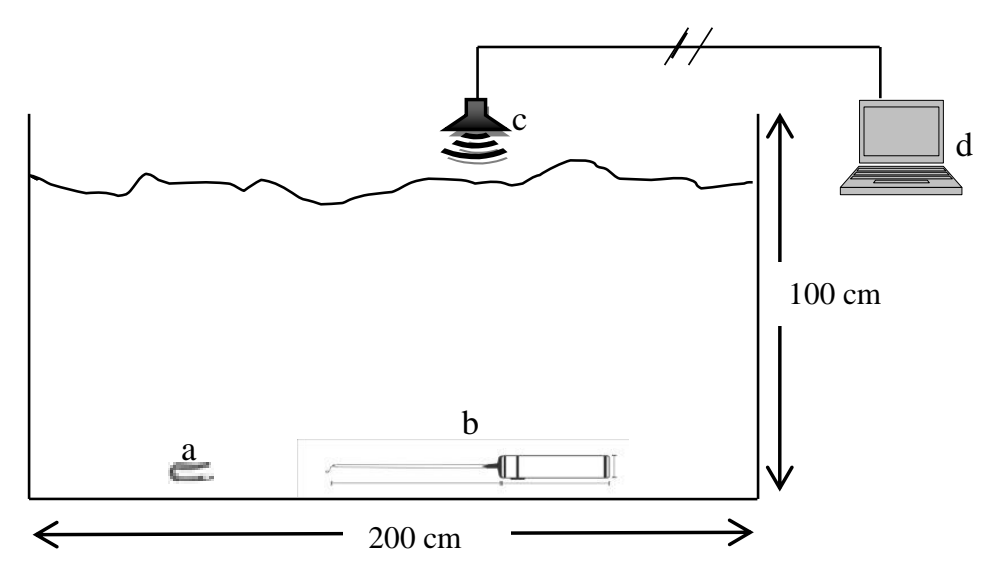

Figure 7. Observation design for response and behavior of Anguilla bicolor. Note: A. A. bicolor, B. Trap, C. Handy camera, D. Observation monitor

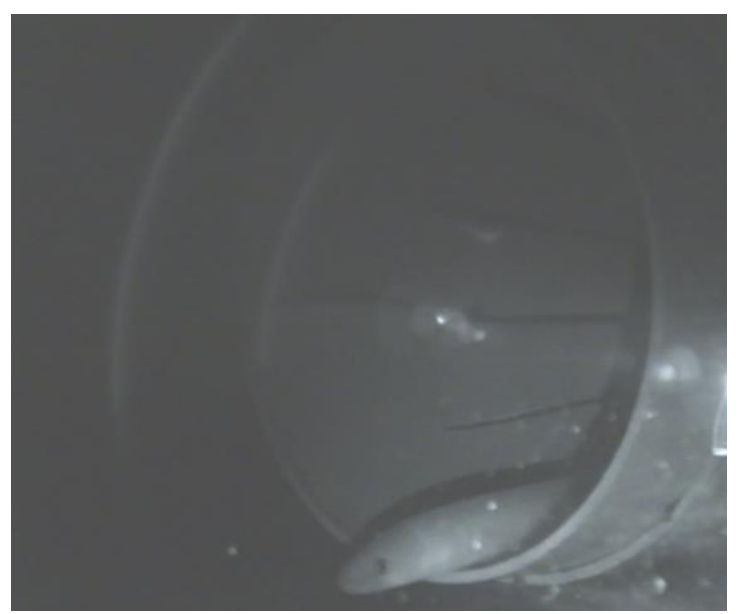

Figure 8. Anguilla bicolor behavior elver stage with trap eel designs from PVC

The other typical response of $A$. bicolor within the presence of a trap was to approach and gain entrance into the trap (Figure 10). This figure illustrated the time response occurred for elver entering in both control and treatment modifications. The quickest response time for the organism towards an eel trap with bait and without a hole is 143 seconds. It indicated that the chemical attractant nature triggers the reaction. Further analyses of all responses showed that A. bicolor elver regards any trap constructions only as protection. It has been known that the predatory and nocturnal fish groups possess the habit of taking shelter and explore prey hunting only when hungry (Fitri et al. 2017a; Fitri et al. 2017b). Furthermore, the organism tends to take cover for longer when compared to the older species (yellow eel and silver eel) with tendency to seek shelters for safety (Baker et al. 2019). The shelter in this context is the trap, which only suits them better, allows hiding from the surroundings (Broadhurst and Millarc 2018; Martasuganda 2003).

The chemical present in the attractant was detected via dispersion that related to the amino acid content of the bait (Weltersbach et al. 2019; Ingólfssona 2017; Ward and Myers 2007; Løkkeborg and Johannessen 1992). Furthermore, nocturnal fish such as Anguilla sp. detects chemical substances through their olfactory organs that are more dominant than others, e.g. eyes (Capoccioni et al. 2018; Fitri et al. 2018, Claveau et al. 2015; Bardonnet et al. 2005). While another organ is lateral line, which detects vibrations in their surroundings for compensating the lack of vision (Aman and Piotrowski 2011).

Eel trap design with an additional hole on the wall, with or without bait, was proven to have not significantly affected the response time of the organism as a juvenile stadium. It means that the perception organ has not adequately developed in comparison with their adult counterparts. Hence, chemical attractants did not affect $A$. bicolor elver (Miller and McCleave 2018; Fitri 2012; Hara 2011; Bergstad 2009). Therefore, it could be stated that the elver organism possesses the behavior of investigating its surroundings (thigmotaxis nature), especially with the presence of foreign objects. However, baits do not affect their response as they only take the eel trap as a space to take shelter from other predators. Furthermore, the ophthalmic organ of A. bicolor does not develop as advanced as its olfactory organ, which is natural for nocturnal biota.

In conclusion, six types of A. bicolor elver stage behavior, manifested with different PVC trap designs were recorded in this study. However, the fastest response time was an eel trap without column and bait. The ANOVA test ( $\mathrm{p}$-value $\leq 0.05)$ showed a significant difference in response time from the four treatments. Hence, the bait makes the organism interested in entering the device, which also functions as a shelter. 


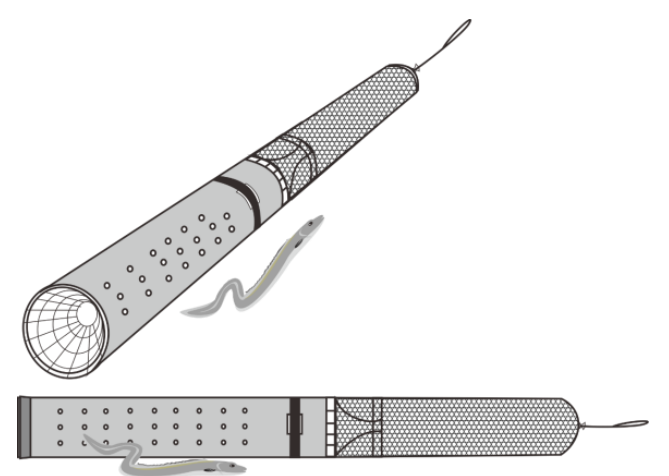

A
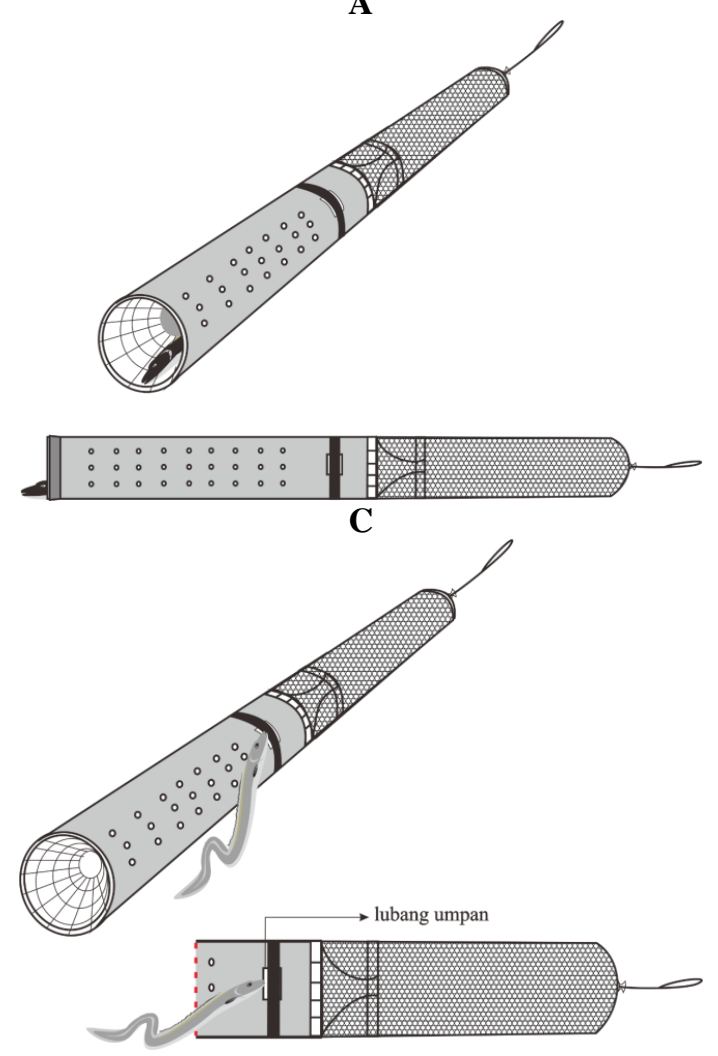

$\mathbf{E}$
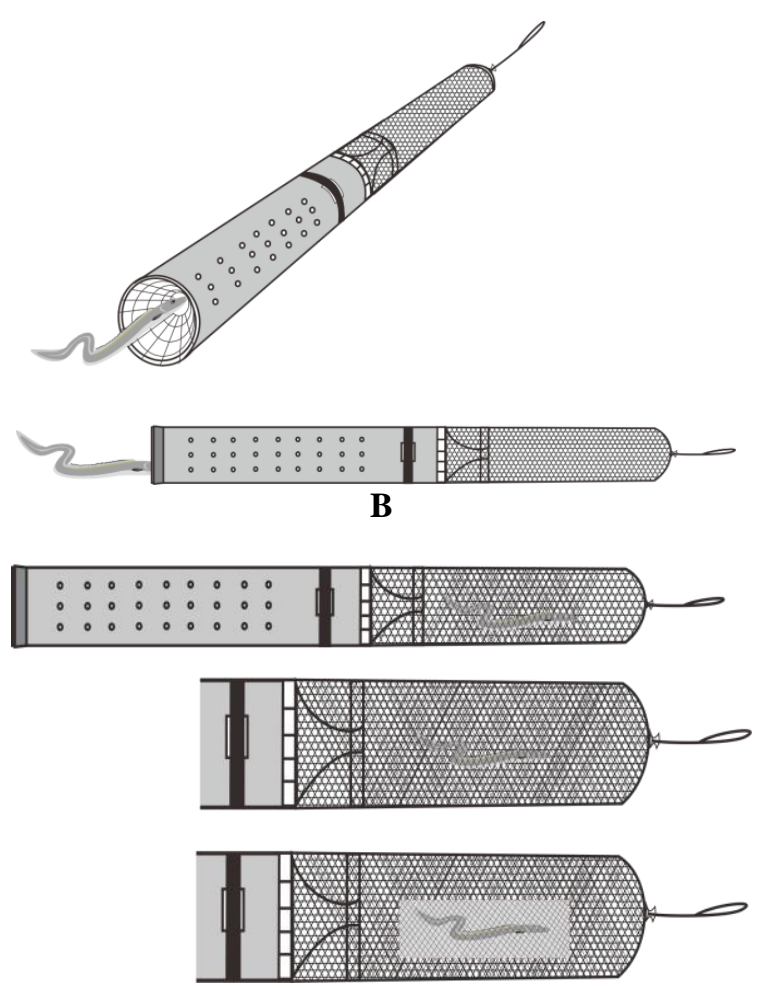

D

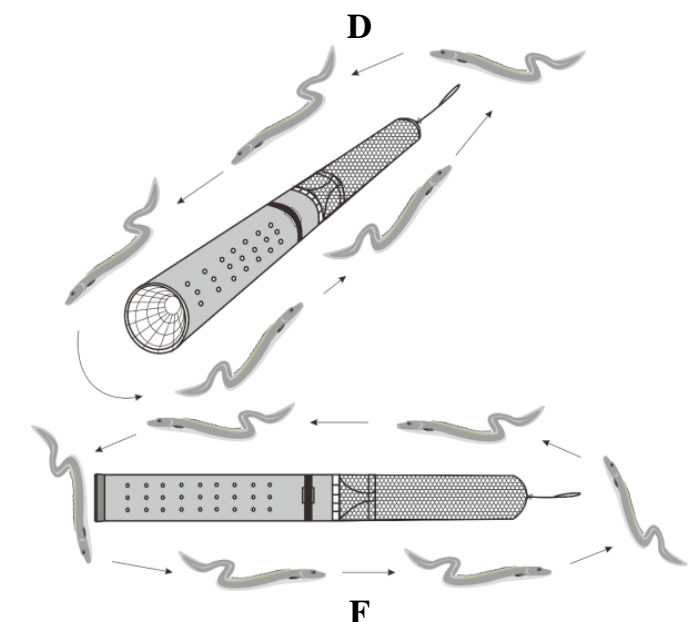

F

Figure 9. An illustration of A. bicolor behavior during capture simulation: (A) Getting into the PVC eel trap; (B) Holding still beside the PVC eel trap; (C) Holding still at the entrance of the device while preventing other fish from coming in; (D) Getting into the bag in the trap; (E) Approaching the bait from outside the device; (F) Moving around the tool

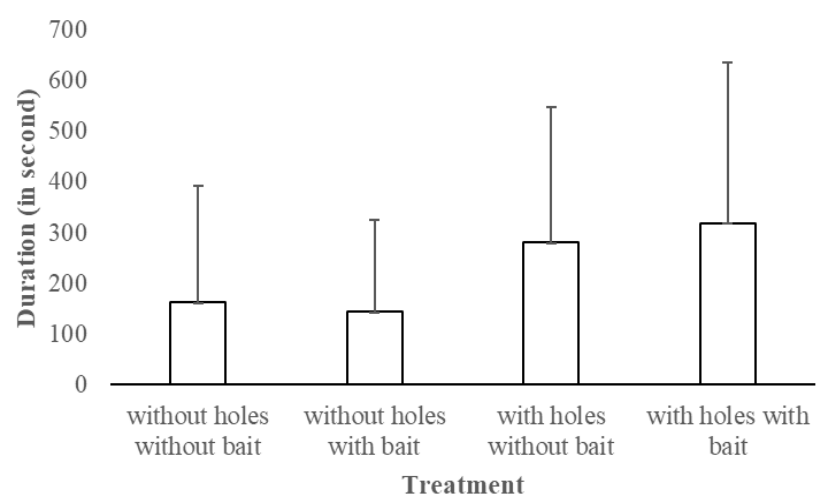

Figure 10. Elver response time upon entering the eel trap

\section{ACKNOWLEDGEMENTS}

The authors are fully grateful to the Indonesian Ministry of Research, Technology and Higher Education for the grant it provides via University Best Basic Research (PDUPT/Penelitian Dasar Unggulan Perguruan Tinggi) program for the 2018 fiscal year. Furthermore, the writers also appreciate Deby and Nanda, team members in the Laboratory of Fish Behavior, Fishing Capture Department of the Faculty of Fisheries and Marine Science, Universitas Diponegoro, Indonesia for their contribution in setting up the experiment and collecting primary data. The authors declare that they have no conflicts of interest. 


\section{REFERENCES}

Aman A, Piotrowski T. 2011. Cell-cell signaling interactions coordinate multiple cell behaviors that drive morphogenesis of the lateral line. Cell Adhes Migr 5: 499-508. DOI: 10.4161/cam.5.6.19113.

Atta KI. 2013. Morphological, Anatomical and Histological Studies on The Olfactory Organs and Eyes of Teleost Fish: Anguilla anguilla In Relation to Its Feeding Habits. J Basic Appl Zool 66(3): 101-108. DOI: 10.1016/j.jobaz.2013.10.002

Bardonnet AT, Bolliet V, Belon V. 2005. Recruitment abundance estimation: role of glass eel (Anguilla anguilla L.) Response to light. J Exp Mar Biol Ecol 321: 181-190. DOI: 10.1016/j.jembe.2005.02.004

Benitez JP, Dierckx A, Matondo BN, Rollin X, Ovidio M. 2018. Movement Behaviours of Potamodromous Fish Within A Large Anthropised River After the Reestablishment of The Longitudinal Connectivity. Fish Res 207: 140-149. DOI: 10.1016/j.fishres.2018.06. 008

Bergstad OA. 2009. Fish: Demersal Fish (Life Histories, Behaviour, Adaptations). Institute of Marine Research Flødevigen His Norway Elsevier Ltd., Nederlands.

Bolliet V, Lambert P, Rives J, Bardonnet A. 2007. Rhythmic swimming activity in Anguilla anguilla glass eels: Synchronisation to wate current reversal under laboratory conditions. J Exp Mar Biol Ecol 344: 54-66. DOI: 10.1016/j.jembe.2006.12.027

Broadhurst MK, Millarc RB. 2018. Relative ghost fishing of portunid traps with and without escape gaps. Fish Res 208: 202-209. DOI: 10.1016/j.fishres.2018.07. 018

Bultel E, Lasne E, Acou A, Guillaudeau J, Bertier C, Feunteun E. 2014 Migration behavior of silver eels (Anguilla anguilla) in a large estuary of Western Europe inferred from acoustic telemetry. Estuar Coast Shelf Sci 137: 23-31. DOI: 10.1016/j.ecss.2013.11. 023

Capoccioni F, Contò M, Failla S, Cataudella S, Ciccotti E. 2018. Fatty acid profiles of migrating female silver eel from Mediterranean Coastal Lagoons as integrative descriptors of spawners biological quality. Estuar Coast Shelf Sci 210: 87-97. DOI: 10.1016/j.ecss.2018.06.017

Chen SC, Chang CR, Han YS. 2018. Seaward migration routes of indigenous eels, Anguilla japonica, A. marmorata, and A. bicolor pacifica, via satellite tags. Zool Stud 57: 21. DOI: 10.6620/ZS.2018.57-21

Claveau J, Monperrus M, Jarry M, Baudrimont M, Gonzalez P, Cavalheiro J, Mesmer-Dudons N, Bolliet V. 2015. Methylmercury effects on migratory behaviour in glass eels (Anguilla anguilla): An Experimental Study Using Isotopic Tracers. Comp Biochem Physiol Part C 171: 15-27. DOI: 10.1016/j.cbpc.2015.03.003

Engman AC, Fischer JR, Kwak TJ, Walter MJ. 2017. Diurnal feeding behavior of the American Eel. A. rostrata .Food Webs 13: 27-29. DOI: 10.1016/j.fooweb.2017.10.003

Fitri ADP. 2012. Fish Behaviour. Diponegoro University Press, Semarang. [Indonesian].

Fitri ADP, Boesono H, Sabdono A, Supadminingsih FN, Adlina N. 2017a The mud crab (Scylla serrata) behavior in different inclination angles of funnel and escape vent for trap net. AACL Bioflux 10 (2): 182190.

Fitri ADP, Boesono H, Sabdono A, Adlina N. 2017b. Resources Management Strategy for Mud Crabs (Scylla spp.) in Pemalang Regency. IOP Conf Ser: Earth Environ Sci 55 12008. DOI: 10.1088/1755-1315/55/1/012008

Fitri ADP, Boesono H, Sabdono A, Nugraheni F. 2018. Different eye physiology of mud crab (Scylla serrata) in different life stage found in Semarang Territorial Waters. Am J Anim Vet Sci 13 (1): 27-35. DOI: 10.3844/ajavsp.2018.27.35

Gutowsky LFG, Sullivan BG, Wilson ADM. 2017. Synergistic and interactive effects of angler behaviour, gear type, and fish behaviour on hooking depth in passively angled fish. Fish Res 186: 612-618. DOI: 10.1016/j.fishres.2016.05.026

Handajani H, Widanarni, Setiawati M, Budiardi T, Sujono. 2018. Evaluation of digestibility and ammonia excretion of fish meal and fish silage fed to juvenile Indonesian Shortfin Eel (Anguilla bicolor). AACL Bioflux 11 (2): 495-504.

Hara TJ. 2011. Morphology of the Olfactory (Smell) System in Fishes Elsevier Inc., Nederlands.
Haryono, Wahyudewantoro G. 2016. Habitat Mapping Distribution of Eel Seed (A. bicolor) and its potential on the South Coast of Java. OMNIAkuatika 12(3): 47-58. DOI: 10.20884/1.oa.2016.12.3.123

Honda S, Muthmainnah D, Suryati NK, Oktaviani D, Siriraksophon S, Amornpiyakrit T, Prisantoso BI. 2016. Current status and problems of the catch statistics on anguillid eel fishery in Indonesia. Mar Res Indon 41: 1-13. DOI: 10.14203/mri.v4lil.94

Ingólfssona ÓA, Einarssonb HA, Løkkeborg S. 2017. The effects of hook and bait sizes on size selectivity and capture efficiency in Icelandic Longline Fisheries. Fish Res 191: 10-16. DOI: 10.1016/j.fishres.2017. 02.017

Lukas AYH, Djokosetiyanto D, Budiardi T, Sudrajat AO, Affandi R. 2017. Optimization of salinity and calcium on Indonesian Shortfin Eel Anguilla bicolor maintenance. AACL Bioflux 10: (4) 951-961

Løkkeborg S., Johannessen T. 1992. The importance of chemical stimuli in bait fishing - fishing trials with presoaked bait. Fish Res 14: 2129. DOI: 10.1016/0165-7836(92) 90070-A

Martasuganda. 2003. Bubu (Traps). Department of Fisheries Resource Utilization. Faculty of Fisheries and Marine Science Bogor Agricultural Institute Bogor, Bogor. [Indonesian]

Miller MJ, McCleave JD. 2018. Eels Encyclopedia of Ocean Sciences, 3rd ed. Elsevier Inc., Nederlands.

Baker N, Haro A, Watten B, Noreika J, Bolland JD. 2019. Comparison of attraction, entrance and passage of downstream migrant American eels (Anguilla rostrata) through airlift and siphon deep entrance bypass systems. Ecol Eng 126: 74-82. DOI: 10.1016/j.ecoleng.2018.10.011

Nijman V. 2015. CITES-listings, EU eel trade bans and the increase of export of tropical eels out of Indonesia. Mar Pol 58: 36-41. DOI: 10.1016/j.marpol.2015.04.006

Pouca CV, Brown C. 2017. Contemporary topics in fish cognition and behaviour. Cur Opin Behav Sci 16: 46-52. DOI: 10.1016/j.cobeha.2017.03.002

Putra DP, Baskoro MS, Wiyono ES, Wisudo SH, Wudianto. 2015. Pengelolaan Perikanan Udang Skala Kecil Dengan Penerapan KoManajemen di Kabupaten Cilacap. Scientific Repository. Bogor Agriculture University, Bogor. [Indonesian]

Righton DA, Metcalfe JD. 2011. Fish Migrations / Eel Migrations Centre for Environment, Fisheries and Aquaculture Science, Lowestoft, UK Crown Copyright Published by Elsevier Inc., Nederlands. DOI: 10.1016/B978-0-12-374553-8.00110-6

Setiawan IE, Mochioka N, Amarullah H, Nakazono A. 2001. Inshore Migration and Spawning Season of The Tropical Eel Anguilla bicolor bicolor Recruiting to The Cimandiri River Estuary, Java Island, Indian Ocean. In: Aida K, Tsukamoto K, Yamauchi K (eds). Proc Int Symp: Adv Eel Biol, The University of Tokyo, Tokyo.

Shiao JC, lizuka Y, Chang CW, Tzeng WN. 2003. Disparities in habitat use and migratory behavior between tropical eel Anguilla marmorata and temperate eel A. japonica in four Taiwanese Rivers. Mar Ecol Prog Ser 261 : 233-242. DOI: 10.3354/meps261233

Shrimpton JM. 2013. Seawater to Fresh Water Transitionsin Diadromous Fishes. In: McCormick SD, Farrelland AP, Braune CJ. (eds.). Fish Physiology Vol. 32 Euryhaline Fishes. Elsevier, New York. DOI: 10.1016/B978-0-12-396951-4.00007-4.

Sugeha HY, Genisa MU. 2015. External and internal morphological characteristics of Glass Eels Anguilla bicolor bicolor from The Cibaliung River Estuary, Banten, Indonesia. Jurnal Oseanologi dan Limnologi Indonesia 41: (1) 37-48. [Indonesian]

Suriyampola PS, Caceres J, Martins EP. 2018. Effect of short-term turbidity on sensory preference and behavior of adult fish. Anim Behav 146: 105-111. DOI: 10.1016/j.anbehav.2018.10.014.

Taqwa FH, Supriyono E, Budiardi T, Utomo NBP, Affandi R. 2018. Optimization of physiological status of glass eel (Anguilla bicolor bicolor) for transport by salinity and temperature acclimatization. AACL Bioflux 11: (3) 856-867.

Verhelst P, Bruneel S, Reubens J, Coeck J, Goethals P, Oldoni D, Moens T, Mouton A. 2018. Selective tidal stream transport in Silver European Eel (Anguilla anguilla L.) - migration behaviour in a dynamic estuary. Estuar Coast Shelf Sci 213: 260-268. DOI: $10.1016 /$ j.ecss.2018. 08.025

Von Brandt. 2005. Fish Catching Methods of the World, 4th ed. Oxford Blackwell Publishing, London.

Ward P, Myers RA. 2007. Bait loss and its potential effects on fishing power in pelagic longline fisheries. Fish Res 86 (1): 69-76. DOI: 10.1016/j.fishres.2007.05.002 
Weltersbach MS, Lewin WC, Gröger JP, Strehlow HV. 2019. Effect of lure and bait type on catch, size, hooking location, injury, and bycatch in the western baltic sea recreational cod fishery. Fish Res 210: 121130. DOI: 10.1016/j.fishres.2018.10. 002
Zydlewski J, Wilkie M. 2013. Freshwater to seawater transitions in migratory fishes. In: McCormick SD, Farrelland AP, Braune CJ. (eds.). Fish Physiology Vol. 32 Euryhaline Fishes. Elsevier, New York. DOI: 10.1016/B978-0-12-396951-4.00006-2. 